\title{
CHINA AND THE THIRTIETH OF SEPTEMBER MOVEMENT
}

\section{Taomo Zhou}

\section{Introduction}

There has been a lot of uncertainty around the role of the People's Republic of China (PRC) in Indonesian politics immediately before and during the Thirtieth of September Movement (Gerakan 30 September, hereafter referred as "G30S"). The idea that Beijing had a hand in G30S has been around since late 1965, when the Indonesian army accused the Chinese government of smuggling arms to the Communist Party of Indonesia (Partai Komunis Indonesia, PKI) for a revolt. ${ }^{1}$ The army's newspaper, Angkatan Bersendjata, later made a more aggressive charge against G30S as being an "abortive communist coup planned and arranged by the Peking regime as part of its concept of world revolution." ${ }^{2}$ The allegation was instilled in the minds of the general population in Indonesia through the film The Betrayal of the PKI (Pengkhianatan G30S/PKI), a propaganda tool of the Suharto regime that was broadcast annually on

Taomo Zhou is a PhD candidate in the Department of History, Cornell University. Her dissertation focuses on the diplomatic relations and transnational social interactions between China and Indonesia during the Cold War. She thanks Chen Jian, Jack Meng-tat Chia, Sherman Cochran, Charles Kraus, Andrew Mertha, Eric Tagliacozzo, and the anonymous reviewer for their comments, and Jeffery Petersen and Carole Atkinson for their help with materials.

1 “262 Putjuk Sendjata Dapat Dirampas,” Duta Masyarakat, October 11, 1965. According to this report, among the 262 pieces of weaponry confiscated in the army's first week of operations against the PKI in the aftermath of G30S, 150 pieces were Tjung rifles.

2 "Kisah Gagalanja Coup Gestapu Jang Dimasak di Peking, I: Rezim Peking perintahkan bunuh 7 Djenderal \& semua Perwira 'Reaksioner'; RRT sanggupi pengiriman sendjata \& perlangkapan untuk 30, 000 orang," Angkatan Bersendjata, April 25, 1966. 
the evening of 30 September for thirteen years and was required viewing for school children. In the film, Chinese doctors were shown practicing acupuncture with electric shocks on the ailing President Sukarno, and their diagnosis of Sukarno's health condition as "critically dangerous" was presented as the trigger for the PKI's coup attempt. ${ }^{3}$ In the English language world, some writers, such as Victor Fic, Jun Chang, and Jon Halliday, have also ventured the claim that Mao Zedong ordered the PKI to carry out the movement. ${ }^{4}$ However, none of the accusations mentioned above is built upon reliable evidence. Our knowledge has been incomplete due to the inaccessibility of related documents from the PRC.

This article intends to clarify the role of the Chinese government during this time in Indonesia by a close reading of the PRC's archival materials. I argue that, although deeply invested in Indonesian politics, Beijing's actual influence over the PKI and the turn of events in Indonesia in 1965 was far more limited than what the Suharto regime and some English language works have previously claimed. Most importantly, this article will present new evidence confirming the claim that PKI chairman D. N. Aidit was a willing participant in G30S. In his meeting with Mao Zedong on August 5, 1965, Aidit sketched out the plan for the movement. ${ }^{5}$ While John Roosa's Pretext for Mass Murder contends that Aidit had good reasons for choosing G30S as a strategy for dealing with the situation he faced, the book does not contain solid evidence pertaining to Aidit's role. ${ }^{6}$ This single PRC document about the Aidit-Mao discussion fundamentally changes how we understand G30S.

The main body of archival evidence presented in this article was obtained during a brief period of unusual access to the archives. G30S has been a topic subject to state censorship in China. Beijing has been restricting access to Chinese governmental documents in relation to G30S, as well as discouraging relevant academic discussions. In November 2008, however, the Chinese Foreign Ministry Archives declassified for the first time Chinese diplomatic documents produced during the years between 1961 and $1965 .^{7}$ The collection comprises documents generated from different levels of the government, ranging from minutes of meetings between top-level Chinese leaders and foreign visitors to low-level communications between Chinese embassies and consulates abroad and in Beijing. Those related to Indonesia amount to over 250 dossiers and almost two thousand pages. However, in summer 2013, the Chinese Foreign Ministry Archives reclassified the main body of its collection, a decision that restricted almost all of the documents used in this paper. Only a very small number of Chinese scholars have published works in Chinese based on those documents.

\footnotetext{
${ }^{3}$ Pengkhianatan G30S/ PKI, directed by Arifin C. Noer, 1984.

${ }^{4}$ Victor M. Fic, Anatomy of the Jakarta Coup: October 1, 1965 (New Delhi: Abhinav Publications, 2004); Jung Chang and Jon Halliday, Mao: The Unknown Story (New York, NY: Anchor Books, 2005), pp. 487-89.

${ }^{5}$ The Aidit-Mao discussion on August 5, 1965, is drawn from a collection entitled "Minutes of Meetings between Chairman Mao and Leaders of Various Communist Parties," which was internally circulated among a group of senior Chinese scholars who had access to the Chinese Communist Party (CCP) Central Archives. I thank Professor Chen Jian for generously sharing this piece of the document with me.

${ }^{6}$ John Roosa, Pretext for Mass Murder: The September 30th Mozement $\mathcal{E}$ Suharto's Coup d'etat in Indonesia (Madison, WI: University of Wisconsin Press, 2006).

${ }^{7}$ This is the second batch of materials declassified at the Chinese Foreign Ministry Archives. The first batch of declassified materials includes documents produced during the years of 1956-60, which were made available to the general public in June 2006.
} 
Moreover, as a form of self-censorship, none of the authors directly touch upon G30S. Besides this body of fresh but currently inaccessible official records in Beijing, evidence is also drawn from the collections of Academia Historica of Taiwan, the extraordinary military court (Mahkamah Militer Luar Biasa) records of Indonesia; Chinese and Indonesian language memoirs; and interviews with witnesses of relevant events in both countries.

I will address the allegations of Beijing's involvement in G30S by first outlining the events currently known to have happened in the small hours of October 1, 1965, and sketching out the development of bilateral relations between Beijing and Jakarta in the early 1960s. Then I will proceed to discuss four issues: Beijing's military aid to Indonesia's Fifth Force; ${ }^{9}$ the potential transfer of nuclear materials and technology from China to Indonesia; Chinese medical aid to the Indonesian President, Sukarno; and the connection between the Chinese Communist Party (CCP) and its Indonesian counterpart, the PKI. The first three issues concern the background of Sino-Indonesian relations in the lead up to the movement, while the final item concerns China's knowledge of and involvement in G30S itself.

\section{Background}

On the early morning of October 1, 1965, Indonesian Army units from the presidential palace guard, led by Lieutenant Colonel Untung, abducted and later killed six senior anti-Communist generals. The kidnappers then announced that a Revolutionary Council composed of left wing, right wing, and neutral political forces had seized power. The Revolutionary Council claimed to have taken President Sukarno under its protection as part of a series of preemptive actions to thwart the coup plans of the Council of Generals, a body of right-wing army generals supported by the United States. Major General Suharto, the head of the Indonesian Army's Strategic Reserve (Komando Cadangan Stategis Angkatan Darat, Kostrad), launched an effective counterattack and regained control of the headquarters of G30S, the Halim airbase, the next day. ${ }^{10}$

Recent research indicates that a clandestine group within the PKI, which included Aidit but excluded other members of the politburo and the rank and file of the party,

\footnotetext{
${ }^{8}$ See Taomo Zhou, "Huaqiao wenti de zhengzhi xuanwo: jiexi zhongguo 1958-1962nian dui yindunixiya zhengce" [The Turbulence Caused by the Issue of Ethnic Chinese in Indonesia, 1958-1962], Cold War International Studies 9 (Summer 2010), pp. 155-74; and Yiping Li and Yuleng Zeng, "1958-1965nian zhongguo dui yinni de yuanzhu" [China's Aid to Indonesia, 1958-1965], Southeast Asian Affairs [Chinese], 3 (2012), pp. 27-36.

9 The "Fifth Force" was a proposal to create a militia group of armed peasants and workers to augment the existing four branches of the Indonesian armed forces: army, navy, and air force, and the police.

${ }^{10}$ For an overview of G30S and the massacres that followed, see Robert Cribb, "The Indonesian Massacres," in Century of Genocide: Critical Essays and Eyewitness Accounts, ed. Samuel Totten, William S. Parsons, and Israel W. Charny, 2nd edition (New York, NY: Routledge, 2004), pp. 233-62. For different interpretations on G30S in English language literature, see Arnold Brackman, Communist Collapse in Indonesia (New York, NY: W. W. Norton \& Company, 1969); W. F. Wertheim, "Suharto and the Untung Coup-The Missing Link," Journal of Contemporary Asia 1 (Winter 1970), pp. 50-57; Benedict Anderson and Ruth T. McVey, A Preliminary Analysis of the October 1, 1965, Coup in Indonesia (Ithaca, NY: Cornell University Southeast Asia Program Publications, 1971); Harold Crouch, The Army and Politics in Indonesia (Ithaca, NY: Cornell University Press, 1978); and Roosa, Pretext for Mass Murder.
} 
planned G30S. The movement aimed to remove senior anti-Communist generals through kidnapping, thereby paving the way for communist hegemony in Indonesian politics. ${ }^{11}$ In the nationwide anti-Communist campaign initiated by Suharto after the movement, a significant number of the ethnic Chinese population were either massacred, arrested and imprisoned, or directly pressured to leave the archipelago, even though some of this ethnic minority collaborated with the Indonesian Army. ${ }^{12}$ In 1967, Beijing suspended diplomatic relations with Jakarta.

One of the main reasons offered for the persecution of ethnic Chinese and the eventual breach of diplomatic ties between China and Indonesia was the alleged involvement of China in G30S. Such accusations arose from the larger background of Chinese-Indonesian bilateral relations in the early 1960s. From 1960 to the months before the movement, China and Indonesia became partners in a postcolonial world. The two countries shared aspirations to replace the bipolar world structure dominated by Moscow and Washington with a more equitable international order that included autonomy for Third World countries. Moreover, the PKI sided with Beijing after the Sino-Soviet split. ${ }^{13}$ High-level visits and cultural, educational, and economic exchanges between the two nations reached a climax between 1964 and 1965. In 1965, in his last Independence Day speech before G30S, Indonesian President Sukarno even declared that "we are now fostering an anti-imperialist axis-the Jakarta-Phnom Penh-HanoiPeking-Pyongyang axis." ${ }^{\prime 4}$

Sukarno's close alignment with China complemented his turn towards the left in Indonesian domestic politics. In 1959, Sukarno replaced constitutional democracy, a system which had been suffering from low efficiency, political instability, and decreasing public support during the earlier years of Indonesia's independence, by establishing a "Guided Democracy." 15 This new institutional framework was a more authoritarian system largely defined by the delicate power dynamics between Sukarno

\footnotetext{
${ }^{11}$ Roosa, Pretext for Mass Murder.

${ }^{12}$ Against the perception that Chinese Indonesians were particularly targeted for violence, Robert Cribb and Charles A. Coppel argue that during 1965-66 the Chinese were not killed on the same scale as were the indigenous ethnic groups (pribumi) that had territorial roots in the country. See Robert Cribb and Charles A. Coppel, "A Genocide that Never Was: Explaining the Myth of Anti-Chinese Massacres in Indonesia, 1965-66," Journal of Genocide Research 11, 4 (December 2009): 447-65. Cribb and Coppel's argument is confirmed by more recent research by Yen-ling Tsai and Douglas Kammen on the Chinese in Medan. See Yen-ling Tsai and Douglas Kammen, "Anti-communist Violence and the Ethnic Chinese in Medan, North Sumatra," in Contours of Mass Violence in Indonesia: 1965-1968, ed. Douglas Kammen and Katherine McGregor (Singapore: National University of Singapore Press, 2012), pp. 131-55.

${ }^{13}$ The PKI was the third largest communist party in the world after the Communist Party of the Soviet Union and the CCP.

${ }^{14}$ Marshal Green, Indonesia: Crisis and Transformation, 1965-1968 (Washington, DC: The Compass Press, 1990), p. 36

15 The very idea of Guided Democracy was probably inspired by Sukarno's visit to China in 1956, during which he was greatly impressed by the progress in China and the effectiveness of the highly centralized political system there. Sukarno established it in 1959 with a presidential decree on May 5 . He did not use the term "Guided Democracy" in the decree, but the substance of this new system was present. On the genealogy of Guided Democracy, see Hong Liu, China and the Shaping of Indonesia, 1949-1967 (Singapore: NUS Press, 2011), pp. 205-30. Studies on Indonesian politics during this period include Daniel S. Lev, The Transition to Guided Democracy, 1957-1959 (Jakarta: Equinox Publishing, 2009); J. D. Legge, Sukarno: A Political Biography (New York, NY: Praeger Publishers, 1972); and Herbert Feith, "Dynamics of Guided Democracy," in Ruth Thomas McVey, ed., Indonesia (New Haven, CT: Southeast Asia Studies, Yale University, by arrangement with HRAF Press, 1963), pp. 309-55.
} 
and the Indonesian Army. ${ }^{16}$ As a result, Sukarno relied heavily on the army's archenemy in domestic politics, the PKI, for organizing public support. In the later period of the Guided Democracy and until G30S, the president's relations with the Indonesian communists became increasingly close, angering the Indonesian Army. In the aftermath of G30S, such antipathy was projected towards the PRC, a perceived foreign sponsor of the PKI.

\section{Chinese Military Aid to Indonesia's Fifth Force}

In early 1965, China encouraged President Sukarno to establish the Fifth Force and initiated a military aid program to Indonesia. The decision was based on the Chinese leadership's perception of increasing Western aggression in Southeast Asia rather than any prior knowledge that G30S was coming. In 1963 and 1964, China hosted two strategic planning meetings to promote revolutions in Southeast Asia. In late September 1963, Zhou Enlai went to Conghua, Guangdong province, to meet with communist leaders from Vietnam, Laos, and Indonesia. Present at the meeting were Ho Chi Minh and Le Duan of the Vietnam Worker's Party, Kaysone Phomvihane from the Lao People's Party, and Aidit of the PKI. ${ }^{17}$ In his keynote speech, Chinese Prime Minister Zhou Enlai proclaimed that Southeast Asia had become the key area of the international anti-imperialist struggle, announcing that "the basic mission of the revolutions in Southeast Asia is against imperialism, feudalism, and comprador capitalism." ${ }^{18}$ To accomplish this goal, Zhou recommended that the communist parties in Southeast Asia should, first, "win over the masses and expand their united fronts"; second, "go deep into the countryside, prepare for armed struggle, and establish base camps;" and, third, "strengthen the parties' leadership." In addition to offering the advice above, Zhou also clarified China's role in the region: "as the reliable home front of the Southeast Asian revolutions, China has the responsibility to fully support antiimperialist struggles in the region." ${ }^{19}$

The inclusion of the PKI in this meeting was significant. ${ }^{20}$ It indicated Beijing's interests in fostering revolution in a broad area of Southeast Asia, rather than Mao's attempt to urge the PKI to wage an armed struggle against Sukarno. On the contrary, China was encouraging the PKI to continue its united front with Sukarno, whose confrontation with Malaysia (known as Konfrontasi) could be exploited by Beijing to counterbalance the Western powers in Southeast Asia. Through Konfrontasi, Indonesia aimed to block Britain's plans to merge the remains of its former Southeast Asian colonies into the Federation of Malaysia. During the years 1963 and 1964, Jakarta was on the brink of war with Malaysia, and its relations with Britain and the United States rapidly deteriorated. Beijing offered Sukarno enthusiastic support by promising to intervene militarily if the Western powers attacked Indonesia. In early 1965, Zhou

\footnotetext{
${ }^{16}$ Feith, "Dynamics of Guided Democracy," p. 323.

${ }^{17}$ Qiang Zhai, China and the Vietnam Wars, 1950-1975 (Chapel Hill, NC: University of North Carolina Press, 2000), pp. 117-19.

${ }^{18}$ Tong Xiaopeng, Fengyu sishinian [Forty Years in All Weather], vol. 2 (Beijing: Zhongyang Wenxian Chubanshe, 1996), p. 219.

${ }^{19}$ Ibid.

${ }^{20}$ Zhai, China and the Vietnam Wars, pp. 117-19.
} 
announced that, as a true friend of Indonesia, China would not "stand by" if Western imperialists dared to invade Indonesia. ${ }^{21}$

Furthermore, although the Chinese revolution had always stood as a possible example for the PKI to follow, the party's position remained that armed struggle was not the best strategy in Indonesia. The PKI had been achieving political success using its united front strategy since the early 1950s. Even as the PKI tilted towards China in the Sino-Soviet split in the early 1960s, it did not change its basic position on the undesirability of armed struggle. The PKI's choice for taking the parliamentary road and making an alliance with Sukarno was also recognized by the CCP as a "correct policy line." When Aidit visited the Central Party School of the CCP in 1963, the head of the school, Kang Sheng, spoke on behalf of the CCP: "[U]nder the leadership of Comrade Aidit, the PKI has ingeniously combined the universal theory of MarxismLeninism and the particular conditions of Indonesian revolution, [and] thereby developed its own systematic theory and policy, which in return enriched the development of Marxism-Leninism." 22 The two strategic planning meetings hosted by the Chinese leaders in 1963-64, then, probably were not intended to change the PKI's view of its strategic position in Indonesia.

In mid-January 1965, Aidit proposed to Sukarno the idea of the Fifth Force-a militia group of armed peasants and workers. ${ }^{23}$ The PKI regarded the Fifth Force as a way to endorse Sukarno's anti-imperialist agenda, and to counterbalance the army. The PKI presented the idea as a way to support Sukarno's Nasakom (NationalismeAgama-Komunisme, nationalism-religion-communism) formula. ${ }^{24}$ Under this formula, even though the PKI would be sure that its members were well-represented in the soon-to-be-created militia, the nationalists (meaning, in effect, the Partai Nasional Indonesia, or the PNI) and religious groups (meaning, in effect, Nahdlatul Ulama, or NU) would also be included in the Fifth Force and thus armed as well. Thus, the creation of the Fifth Force would benefit the PKI, but not exclusively. Yet the PKI leaders envisaged that, in the long term, the Fifth Force would help the PKI gain an edge on its rivals and facilitate the party's gradual ascendance to state power.

According to the memoirs of Subandrio, the first deputy prime minister of Indonesia at the time, Sukarno came up with the idea of the Fifth Force in 1965 as a way to accommodate the unconditional military aid for forty battalions offered by China by the end of $1963 .{ }^{25}$ This probably is not true. Beijing's enthusiasm for military aid to Indonesia only began to emerge during the latter half of 1964 . Between 1960 and 1963, Beijing "refused most of Indonesia's requests for military aid; [and] only agreed

\footnotetext{
${ }^{21}$ Zhou used the same strong wording as the declaration made before Beijing entered the Korean War, "women buhui buguan" [we will not stand by]. See "The Second Meeting between Prime Minister Zhou Enlai, Vice Prime Minister Chen Yi, and Indonesian First Deputy Prime Minister Subandrio," January 25, 1965, Chinese Foreign Ministry Archives, 105-01910-02.

22 "Comrade Aidit Was Invited to Give a Political Report at the Central Party School," Remin Ribao [The People's Daily], September 3, 1963.

${ }^{23}$ Harian Rakjat, January 15, 1965. Aidit said that there were ten million peasants and five million workers ready to be armed. Cited in Crouch, The Army and Politics in Indonesia, p. 87.

${ }^{24}$ Harian Rakjat, May 19, 1965, cited in Crouch, The Army and Politics in Indonesia, p. 87.

${ }^{25}$ Dr. H. Soebandrio, Kesaksianku tentang G-30-S (Jakarta: Forum Pendukung Reformasi Total, 2001), pp. $17-28$.
} 
to partially fulfill a limited number of requests." ${ }^{26}$ Sukarno himself, on the other hand, claimed that Zhou Enlai had first suggested the idea of a Fifth Force consisting of the twenty-one million volunteers who had registered themselves during $1964 .{ }^{27}$ Sukarno's claim, although plausible, cannot be verified by archival evidence from the PRC. However, it can be confirmed that Beijing strongly endorsed the idea of the Fifth Force. In late-January 1965, while Subandrio was visiting China, Zhou Enlai said to him:

The proposal by President Sukarno to militarize the reliable masses is absolutely correct. Your president is the Supreme Commander of the Indonesian Navy, Army, Air Force, and Police Force. There should be an additional force-a militia. And Sukarno should be the supreme commander of the militia, too. Of course, this has to be established gradually. The militia can defend the motherland's territory, airspace, and territorial waters. In addition, because the militia is composed of civilians, it can also easily facilitate the people's guerilla warfare in North Kalimantan ... militarized masses are invincible ... I am sharing with you our own experience. Please pass this on to the President. ${ }^{28}$

The Indonesian Army strongly opposed the proposal for the Fifth Force, and was implicitly opposed to China's involvement in the matter. The Indonesian minister of defense, General Abdul Haris Nasution, ${ }^{29}$ openly declared that "it is not possible for a force to work if its commander must be from the PNI, with deputies from the religious and Communist groups." ${ }^{30}$ Chief of staff of the Indonesian Army, General Ahmad Yani, ${ }^{31}$ then devised a formula that enabled the army leaders to pay lip service to the Nasakom concept while sidetracking the proposal. ${ }^{32}$ China's endorsement of the idea was also used by the Indonesian Army for its campaign against the Fifth Force. On June 29, June 30, and July 1, 1965, Angkatan Bersenjata published, in installments, a long article entitled "The Fifth Force is Not Suitable for the Objective Conditions in Indonesia," as part of the army's systematic propaganda effort to block the proposal. ${ }^{33}$ The author, a Colonel Lapase, argued, by quoting sources "from the Chinese embassy in Indonesia," against establishing a Fifth Force because of the differences between the Chinese and Indonesian political systems. According to him, the two governments had different structures; and the socialist system in China was far more advanced than the one in Indonesia. He asserted:

In Indonesia, there are nine or ten political parties that were all fairly strong. But in China, there was only one ruling party. In other words, in China, the major political influence only came from one source, and there was only one political

26 "Our Friendly Relations with the Indonesian Military and Our Military Aid to Indonesia," January 4, 1963, Chinese Foreign Ministry Archioes, 105-01560-02.

${ }^{27}$ Berita Yudha, June 2, 1965. Cited in Crouch, The Army and Politics in Indonesia, pp. 89-90.

${ }^{28} \mathrm{Ibid}$. The suggestion was repeated in "Diplomatic Bulletin on Indonesian First Deputy Prime Minister Subandrio's Visit and Bilateral Negotiations," February 2, 1965, Chinese Foreign Ministry Archizes, 10501318-05.

${ }^{29}$ Originally a kidnapping target during G30S, Nasution survived due to mistaken identity. He served at his pre-G30S position until February 1966, and as the chief of staff of the armed forces until 1967.

${ }^{30}$ Berita Yudha, May 25, 1965. Cited in Crouch, The Army and Politics in Indonesia, p. 88.

${ }^{31}$ Yani was killed by members of G30S during an attempt to kidnap him from his house.

${ }^{32}$ Crouch, The Army and Politics in Indonesia, p. 88.

${ }^{33}$ Kolonel Lapase, "Angkatan ke-V tidak tjotjok dengan suasana obdjektif di Indonesia I, II dan III," June 29, 30, and July 1, 1965, Angkatan Bersenjata. 
ideology. Thus, in China, it was easier to maintain unified control over the militia. However, in Indonesia, it would be quite difficult. ${ }^{34}$

Lapase concluded that the laborers, peasants, youth, and students should be armed, but that they should not be organized into a separate military force. ${ }^{35}$

China was alarmed by this name-calling in the debate surrounding the Fifth Force. Having paid a visit to the Chinese military attaché on June 24, 1965, Lapase had put forward a request for clarifications on the idea of "the Fifth Force" and received a carefully worded introduction on China's militia. In a telegram to the Foreign Ministry in Beijing following the publication of the articles, the Chinese embassy in Jakarta criticized itself for "not being vigilant about his intentions," as in hindsight "Lapase was clearly using the chance to borrow the name of the Chinese embassy in order to obstruct the establishment of the Fifth Force." ${ }^{36}$ The Chinese military attache office in Jakarta reported to Beijing that "Sukarno ... wanted to use this opportunity to establish an additional military force so as to counterbalance the army. The left-wing groups supported the idea, hoping to take the chance to militarize the workers and peasants. Yani opposed, because he wanted to maintain the status quo ... The air force is not resigned to giving away the issue to the army." ${ }^{37}$ Another analytical report recommended a more cautious policy line towards the issue of the Fifth Force:

The current debate concentrates on two questions: whether the workers and peasants should be militarized and whether another military force should be established. Our research suggested that the answer to the first question is affirmative. As for the second question, it is worthwhile to consider the possibility, although we should not promote our own experience to the extreme. Overselling the idea will invite attacks from the right wing. Yet based on the situation in Indonesia, an additional military force will help counterbalance the Indonesian Army. ${ }^{38}$

Despite the divergent domestic opinions on the Fifth Force, in late June 1965 a delegation of Indonesian volunteers was dispatched by Sukarno to visit China, North Korea, and Vietnam to learn about the militia in those three countries. The group was commissioned to gather information on how political institutions, power structures, chains of command, and ideology affected the mobilization and militarization of the masses. During their stay in China, the head of the delegation, Colonel Willy Sujono, ${ }^{39}$

\footnotetext{
${ }^{34}$ Kolonel Lapase, "Angkatan ke-V tidak tjotjok dengan suasana obdjektif di Indonesia II," Angkatan Bersenjata, June 30, 1965.

${ }^{35}$ Kolonel Lapase, "Angkatan ke-V tidak tjotjok dengan suasana obdjektif di Indonesia III," Angkatan Bersenjata, July 1, 1965.

36 "On Establishing the 'Fifth Force' in Indonesia," June 25-July 12 1965, Chinese Foreign Ministry Archives, 105-01694-02.

${ }^{37}$ Ibid.

38 "On a Delegation of Indonesian Volunteers' Visit to China," June 23, 1965, Chinese Foreign Ministry Archives, 105-01689-01.

${ }^{39}$ On the identity of Willy Sujono, according to an intelligence report about East Java, Sujono was the commander for the Madiun area. The report compliments him for being very firm in dealing with the PKI. See "Report from East Java," Indonesia 41 (April 1986), pp. 137, 142. However, in a declassified report by a CIA agent, Richard Cabot Howland, Sujono was commander of the Kediri area and had been a key informant for Stanley Karnow, a journalist who wrote in 1966 some of the best reports about the mass violence in the aftermath of G30S. Howland got his information from the American Baptists in Kediri, who
} 
revealed to his Chinese counterparts that there was a total of twenty million people registered with Indonesia's volunteer troops, although, relative to Indonesia's population (about 105 million in $1965^{40}$ ), the proportion remained still very small in his opinion. Some volunteers were sent to North Kalimantan to educate the masses, to open up wastelands, and to establish base camps. Willy Sujono said Indonesia could not arm the people all at once, because the counter-revolutionaries would take advantage of the situation. Therefore, in Indonesia, the "improvement of the people's consciousness should come first, organization of the masses should come second, and militarization should be the last step. ${ }^{\prime 41}$

When receiving the delegation of Indonesian volunteers, the Chinese leaders took a more moderate stance. On June 29, 1965, General Luo Ruiqing, the chief of the People's Liberation Army General Staff, told the delegation, "Whether you can follow the Chinese experience is a question only you can answer for yourself based on the situation in Indonesia. Our experience is just for your reference. Every country's circumstances are different. We all have to start from the specific circumstances of our own country." ${ }^{42}$ When Zhou Enlai met with the delegation, he also emphasized that, geographically, Indonesia was very different from China. China lacked the experience of military operations on islands. Indonesia had to work out a method that suited its own situation the best. ${ }^{43}$

The question of the Fifth Force remained undecided before G30S. At his Independence Day speech on August 17, 1965, Sukarno promised that only "after considering the matter more deeply ... I shall make a decision on this matter." ${ }^{44}$ The Indonesian Air Force, with fraught relations with the army, welcomed the idea of a fifth force. Its commander, Vice Marshal Omar Dani, declared, "How tremendous our strength would be if the People, as the fifth force, were armed like the other four forces." ${ }^{45}$ Although no agreement had been reached on the Fifth Force, in the months before G30S, around two thousand members of the PKI or PKI-affiliated organizations received a brief military training course for several weeks at Halim air base.

Whereas the idea of the Fifth Force stirred up much commotion in the public sphere, the Chinese arms deal was negotiated behind the scenes between the top leaders of China and Indonesia. In January 1965, Beijing voluntarily proposed to offer

suspected that Sujono had been sympathetic to the PKI before G30S and was just trying to avoid attacks in supporting the killings of the PKI members and sympathizers. See Richard Cabot Howland, "The Lessons of the September 30 Affair," available at https: / www.cia.gov/ library/ center-for-the-study-ofintelligence/kent-csi/vol14no2/pdf/v14i2a02p.pdf, pp. 23-26, accessed July 14, 2014. I thank John Roosa for generously sharing the information on Willy Sujono.

${ }^{40} \mathrm{http}$ :/ / www.populstat.info/ Asia/indonesc.htm, accessed July 15, 2014.

41 "Briefing on Receiving the Delegation of Indonesian Volunteers," July 1-2, 1965, Chinese Foreign Ministry Archives, 105-01689-07.

42 "Minutes of the Meetings between the Chief of the PLA General Staff Luo Ruiqing, Secretary of CCP Central Political and Legislative Committee Peng Zhen, and the Delegation of Indonesian Volunteers," June 29,1965, Chinese Foreign Ministry Archives, 105-01689-02.

43 "Minutes of the Meting between Prime Minister Zhou Enlai and the Delegation of Indonesian Volunteers" (on Afro-Asian conference and other issues), July 11, 1965, Chinese Foreign Ministry Archives, 105-01689-03.

${ }^{44}$ President Sukarno's speech, August 17, 1965, cited in Crouch, The Army and Politics in Indonesia, p. 93.

${ }^{45}$ Harian Rakjat, June 7, 1965, cited in Crouch, The Army and Politics in Indonesia, p. 90. 
Indonesia small arms. During a meeting with a group of military personnel (including the commander-in-chief of the navy, chief of the police force, chief of the State Intelligence Agency, and the first assistants of the commander-in-chief of the army and the air force) who visited China together with Subandrio, Luo Ruiqing said: "Now we can produce in large quantity light weapons for the infantry. If you are in need of small weapons, we can help. If your navy or air force needs any spare parts, please feel free to send your staff over to China to have a look." ${ }^{46}$ During his meeting with Subandrio, Mao Zedong also said: "The most important weapons are the light weapons ... the crucial issue is to deal with the enemies within 200 meters." $^{\prime 47}$

Made on the government-to-government level, China's original offer was probably designed with the whole country and all four services in mind. Ultimately, only the air force asked for the small arms. In February 1965, Subandrio informed Yao Zhongming, the Chinese ambassador to Indonesia, that "President Sukarno has agreed to accept the small arms offered by China. ${ }^{48}$ Subandrio said that the president would soon dispatch a special envoy for discussion on the technical details. However, the deal was set aside for four months, probably delayed by the heated debate on the Fifth Force. In late June 1965, Commodore Andoko, who would later accompany Sukarno's emissary for this secret deal, Dani, on a secret trip to China in mid-September, approached the Chinese military attaché in Jakarta and informed the latter that the Indonesian air force had decided to "militarize the people within the fifty kilometer parameter range of Halim Air Base." ${ }^{\prime 49}$ The purpose for the militarization program, according to him, was to "prevent destruction by imperialists and domestic subversives." ${ }^{50}$ Andoko also stated that the Indonesian Air Force would send planes to pick up the weapons, and requested that the Chinese military attaché consider how to deliver the weapons to the Indonesian Air Force directly. When the Chinese military attaché showed concerns and reluctance to do so, Andoko pressured him. "If one has to wait for a unanimous agreement among the four forces [army, navy, air force, and the police], it will be too late." ${ }^{51}$ However, the Chinese military attaché insisted that a decision should be made by state leaders and carried out through government-to-government channels. ${ }^{52}$

It seems likely that the Indonesian Air Force was using the protection of Halim airbase as a justification for its own request for small arms, which was made under the auspices of President Sukarno. Sukarno might have appointed Dani as his envoy to attend to the details of the deal precisely so that the air force would receive the

46 "Minutes of the Meetings between the Chief of the PLA General Staff Luo Ruiqing and the Military Personnel from the Indonesian Delegation," January 27, 1965, Chinese Foreign Ministry Archives, 105-01910-07.

47 "Meeting between Chairman Mao Zedong and Indonesian First Deputy Prime Minister Subandrio," January 27, 1965, Chinese Foreign Ministry Archives, 105-01910-04.

48 "Briefings on the Meeting between our Ambassador to Indonesia Yao Zhongming and Indonesian First Deputy Prime Minister Subandrio," February 11, 1965, Chinese Foreign Ministry Archives, 105-01319-05.

49 "On the Indonesian Air Force's Request for Weapons to Militarize the People Living in the Areas Surrounding the Halim Airbase," July 2, 1965, Chinese Foreign Ministry Archives, 105-01697-02. A circle centered on Halim with a diameter of fifty kilometers covers a large area. The air force was probably not planning on arming the people in the immediate vicinity of Halim airbase to protect the airfield. Andoko was most likely just justifying the air force's request for a large amount of arms.

${ }^{50}$ Ibid.

${ }^{51}$ Ibid.

${ }^{52}$ Ibid. 
weapons rather than the army, navy, or police. Sukarno probably wanted to build up the air force, whose officers were considered as more loyal to him, to counterbalance the army, whose officers were less so. The Chinese seemed to have understood fully that the arms were meant to support the air force in its struggle against the rightwingers in the army, and the protection of Halim was used as an excuse. In an analytical report written by the Chinese military attaché, which made no mention of Halim, the reasons for the Indonesian Air Force's urgent request were interpreted as the following:

- The air force wanted to use the chance to push for the militarization of all workers and peasants.

- The air force is preparing to respond to the sudden attack by the imperialists and destructions by the subversives.

- The air force is making long term plans for strengthening its power, especially against the scenario of a sudden attack from the right wing. ${ }^{53}$

The military attaché concluded that "The embassy recommends that if the air force put forward its request via the Indonesian Government, we might consider fulfilling its request to a moderate extent." ${ }^{54}$

Despite Beijing's initial concerns over being approached by the air force alone, Zhou Enlai and Dani probably had reached an agreement on September 17, 1965, in Beijing. During his visit to Indonesia in late August 1965, Chen Yi reassured Subandrio that "we can offer our weapons for free. ${ }^{\prime 55}$ On September 13, 1965, Dani met with the Chinese military attaché in Jakarta, announcing that the air force hoped to receive 25,000 pieces of small arms out of the total of 100,000 items that China offered to Indonesia. Dani repeated the claim that these weapons would be used to equip the workers and peasants near Halim Airbase. In addition, Dani emphasized that Sukarno had approved the air force's request, together with the police force's request for 20,000 items. ${ }^{56}$ On September 16, the day when Dani arrived in Beijing, the Chinese embassy in Jakarta sent a telegram back to the Foreign Ministry: "The President and Subandrio had agreed on the small weapons deal [with regard to Dani's request]. We can fulfill their [the air force's] request for 25,000 pieces. But we suggest that we could deliver a little less than that." ${ }^{57}$

There is no hard evidence confirming that the Chinese leaders in Beijing did take the advice from the Embassy and give a green light to the deal. However, available information indicates that Beijing was inclined to support the Air Force in strengthening itself against the right-wingers in the army. In general terms, the

\footnotetext{
${ }^{53}$ Ibid.

${ }^{54}$ Ibid.

55 "The Private Meeting between Vice Premier Chen Yi and Indonesian First Deputy Prime Minister Subandrio," August 22, 1965, Chinese Foreign Ministry Archives, 105-01912-09.

56 "Plans for Receiving the Commander of the Indonesian Air Force, Staff from the Pakistani Air Force and the Name List of the Delegation of Pakistani Air Force," September 13, 1965, Chinese Foreign Ministry Archives, 204-01123-02.

57 "Plans for Receiving the Commander of the Indonesian Air Force, Staff from the Pakistani Air Force and the Name List of the Delegation of Pakistani Air Force," September 16, 1965, Chinese Foreign Ministry Archives, 204-01123-02.
} 
purpose of Dani"s trip was to "discuss the military aid to Pakistan, the cooperation among the air forces in China, Indonesia, and Pakistan, and our [Chinese] military aid to Indonesia." ${ }^{58}$ On the morning of September 17, Zhou Enlai had a three-hour meeting with Dani and the Indonesian Ambassador to China, Djawato, the minutes of which have not been declassified. According to a published official record of Zhou Enlai's diplomatic activities, Zhou expressed to Dani his concerns over the second Afro-Asian conference and his wish for further discussions on this topic with President Sukarno and Subandrio. ${ }^{59}$ After Dani's return to Indonesia, Aidit secretly informed the Chinese Embassy in Indonesia that Dani told him "the Chinese comrades recognize that it is very important to support Pakistan, but it is even more important to defend Indonesia." Dani was "very much touched," and thought the Chinese take on the situation was "absolutely correct." ${ }^{60}$

Even if the leaders in Beijing did approve the Indonesian Air Force's request, however, given the limited window of opportunity between Dani's visit and the outbreak of G30S, it would have been logistically difficult for the Indonesian Air Force to arrange for and receive the shipment. Dani was quoted as having said in his confession at the extraordinary military court (Mahkamah Militer Luar Biasa) that the Chinese leaders asked the Indonesian Air Force to make its own arrangements for the transportation of small arms since China was experiencing economic difficulties. ${ }^{61}$ Although these court records are usually unreliable, this statement can be verified by the details of Commodore Andoko's meeting with the Chinese military attache in late June 1965, as mentioned earlier in this paper. In addition, according to the former director of the Indonesian Nuclear Agency (Badan Tenaga Atom Nasional, BATAN), Djali Ahimsa, who visited China between September 21 and October 6, 1965, he met Sri Mulyono Herlambang, from the Indonesian Air Force, in Beijing shortly before G30S. The latter claimed to have come with President Sukarno's private plane with a mission "to request the Chinese government deliver the weapons it had promised earlier." 62 This piece of information suggests that the details of the deal were probably not fully concluded, or at least that most of the weapons under negotiation had not been processed for delivery (which involves at least time-consuming assembling and packing, aside from the paperwork) a week before G30S. Although one cannot fully deny the possibility that the Indonesia Air Force managed to ship some of the weapons from China to Indonesia, the under-armed status of the militia groups involved in G30S at the Halim air base suggests that the weapons most probably had not arrived in Indonesia. ${ }^{63}$

\footnotetext{
58 "Approval of Plans for Receiving the Commander of the Indonesian Air Force," September 15, 1965, Chinese Foreign Ministry Archives, 204-01174-01.

${ }^{59}$ Research Centre for Diplomatic History at the Ministry of Foreign Affairs of the People's Republic of China (PRC), Zhou enlai waijiao huodong dashiji [The Chronology of Zhou Enlai's Activities in Foreign Affairs](Beijing: Zhongyang wenxian chubanshe, 1993), pp. 477-78.

60 "Analysis by Our Embassy in Jakarta on Indonesia's Position of Supporting Pakistan while Opposing Indian Aggression," September 25, 1965, Chinese Foreign Ministry Archives, 105-01679-04.

${ }^{61}$ Omar Dani, Berkas perkara Omar Dani, ex laksamana madya udara dalam peristiwa Gerakan 30 September (Djakarta: Mahkamah Militer Luar Biasa, 1966), p. 17

${ }^{62}$ Interview with Djali Ahimsa, Jakarta, April 18, 2013. Djali Ahimsa could not recall the exact date of this meeting, but the earliest possible time is September 22, 1965.

${ }^{63}$ See Anderson and McVey, A Preliminary Analysis of the October 1, 1965, Coup in Indonesia, p. 21; and Roosa, Pretext for Mass Murder, pp. 45-46.
} 
In addition, in terms of quantity, Chinese military aid lagged far behind that from the Soviet Union. During his visit to Indonesia in 1960, Khrushchev generously granted US $\$ 100$ million, one of the largest grants of Soviet foreign aid to a noncommunist country at the time. ${ }^{64}$ In the following years, Moscow supplied a significant number of weapons for Konfrontasi. ${ }^{65}$ According to a report by the Chinese military intelligence agency shortly before G30S, between 1960 and September 1965:

... the Soviet Union had signed four military aid pacts that offered total aid of US\$1,126,000,000. Between 1960 and 1963, Moscow provided navy and air force equipment worth US\$950,000,000. In 1964, the Soviets offered US\$176,000,000 worth of equipment to the Indonesian Army, but some of the promised items had not arrived. Ninety percent of Indonesian Air Force equipment and 80 percent of Indonesian Navy equipment came from the Soviet Union. ${ }^{66}$

A Japanese intelligence agency, Mainland China Research Institute, estimated that the Soviet military aid to Indonesia ranged from US\$600,000,000 to US\$1,200,000,000, and made an assessment similar to Beijing's- "Eighty to 90 percent of Indonesian Air Force and Navy equipment was supplied by the Soviet Union." ${ }^{67}$ Experts within the Mainland China Research Institute observed that "the Chinese aid cannot compare with the Soviet aid, and seemed unable to catch its level." ${ }^{68}$ Archival evidence from the United States also indicated that "[T]he Indonesian military establishment is almost totally Soviet-supplied. ${ }^{\prime \prime 9}$ It is thus difficult to determine whether the Chinese military aid had any significant impact on Indonesian politics in 1965.

\section{Potential Transfer of Nuclear Materials and Technology from China to Indonesia}

Aside from agreeing to supply small arms, in the early months of 1965, before G30S, China was contemplating a possible transfer of nuclear technology to Indonesia. In the late 1950 s and early 1960s, China's confrontation with the United States continued as its alliance with the Soviet Union was disintegrating. Beijing's leaders made developing nuclear weapons a top priority, not only to improve its strategic position vis-à-vis both superpowers, but also to enhance the Chinese Communist Party's claims of legitimacy at home, especially in the wake of the failure of the Great Leap Forward. Out of both domestic and international considerations, Mao and his comrades were eager to demonstrate that a developing country also had the capability to develop

\footnotetext{
${ }^{64}$ Ragna Boden, "The 'Gestapu' Events of 1965 in Indonesia: New Evidence from Russian and German Archives," Bijdragen tot de Taal-, Land-en Volkenkunde (BKI) 163,4 (2007), p. 511.

${ }^{65}$ Ibid.

${ }^{66}$ "Indonesia's Relations with the Soviet Union," August 4-September 10, 1965, Chinese Foreign Ministry Archives, 105-01680-02.

67 "The Bandits' Relations with Indonesia, 1965," October 1-December 31, 1965, Academia Historica, 02000001910A. "Bandit" was the standard reference to the communist regime in mainland China by the Kuomintang regime in Taiwan. This is a piece of a Japanese intelligence report that was shared with the Kuomintang regime in Taiwan and translated into Mandarin by the Taiwanese consulate in Osaka.

${ }^{68}$ Ibid.

${ }^{69}$ The Office of Current Intelligence, Central Intelligence Agency, "Indonesian Army Attitudes towards Communism," November 22, 1965, Johnson Library, National Security File, Country File, Indonesia, Vol. VI, November 1965-May 1966. Cited from Foreign Relations of the United States, 1964-1968, volume XXVI, Indonesia; Malaysia-Singapore; Philippines, document 178, available at https: / history.state.gov/ historicaldocuments / frus1964-68v26/d178, accessed August 4, 2014.
} 
nuclear technology on its own. The first Chinese nuclear bomb was successfully detonated on October 16, 1964.

As a signatory of the 1963 Limited Nuclear Test Ban Treaty, ${ }^{70}$ Indonesia's initial reaction to China's successful nuclear test was ambivalent. When the Chinese Ambassador Yao Zhongming met with Subandrio to probe the Indonesian government's stance on China's successful nuclear test, Subandrio offered only a few superficial congratulatory words before raising the sense of insecurity felt among AfroAsian countries and his concerns over "pollution caused by radioactive dust and ashes." ${ }^{71}$ Given that these two issues were unrelated, Subandrio was probably using the environmental impacts of China's nuclear test as an excuse to express Indonesia's discontent. Subandrio further explained, which was not soothing to Beijing's ears, that if he mentioned how good and how marvelous China's nuclear test was, others would say that Indonesia was China's "tail" and a member of the "Chinese bloc." At the time, China had been protesting against the Conference on Disarmament in Geneva, which was regarded by Beijing as an arrangement made under the auspices of the Western imperialists. Although Beijing needed Jakarta's support in this regard, Subandrio took a middle course on the issue. The Foreign Ministry in Beijing seemed resentful of Subandrio's political savvy:

$\mathrm{He}$ [Subandrio] is collaborating with the imperialists and the revisionists in their conspiracy to oppose the nuclear test in China. It seems that Subandrio is not only trying to give us a hard time, but also to take the chance to start negotiating with the United States and the Soviet Union. ${ }^{72}$

Subandrio's lukewarm attitude would completely change later due to Sukarno's passionate pursuit of a nuclear weapon and the prospects of obtaining support from China. Indonesia's Institute of Atomic Energy (Lembaga Tenaga Atom) was established in December 1958. Under the terms of a five-year bilateral agreement, the United States provided Indonesia with US\$491,000 in financial aid to develop its atomic research program for civilian use. A small 250-kilowatt research reactor purchased from the United States was installed at the Bandung Institute of Technology in 1961 and its construction was completed in $1964 .{ }^{73}$ At the same time, the Soviet Union offered to build Indonesia two small research reactors. The first one was completed in Bandung in November 1962 and a deal to purchase another 2,000kilowatt reactor was signed in January $1964 .{ }^{74}$ Starting from 1964, as Indonesia's

\footnotetext{
${ }^{70}$ Indonesia signed the 1963 Limited Test Ban Treaty on October 7, 1963, in Moscow. The LTBT outlawed nuclear weapon tests in the atmosphere, underwater, or outer space, but did not restrict underground testing. Quoted from Robert M. Cornejo, "When Sukarno Sought the Bomb: Indonesian Nuclear Aspirations in the Mid-1960s," The Nonproliferation Reviezv, Summer 2000, p. 32.

71 "The Indonesian Government's Attitude towards our Proposal for a Summit Conference of All Countries of the World on the Complete Prohibition of Nuclear Weapons, October 19-November 19, 1964," Chinese Foreign Ministry Archives, 105-01870-01.

${ }^{72}$ Ibid.

${ }^{73}$ See: US Department of State, "Agreement for Cooperation between the Government of the United States of America and the Government of the Republic of Indonesia Concerning Civil Uses of Atomic Energy," June 1960, TIAS no. 4557, United States Treaties and Other International Agreements, vol. 11, pt. 2; Daniel B. Poneman, "Indonesia," in Nuclear Power in Developing Countries, ed. James E. Katz and Onkar S. Marwah (Lexington, MA: Lexington Books, 1982), pp. 183-85; and noted in Cornejo, "When Sukarno Sought the Bomb," p. 32.

74 "The Bandits' Relations with Indonesia, 1965," Academia Historica.
} 
relations with both the Western and Socialist blocs became fraught with tension, Sukarno showed great interest in transforming Indonesia's limited, peaceful use of nuclear energy into making nuclear weapons. Sukarno believed that this was the key to improving his country's international status. China indicated its intention to help Sukarno achieve such a goal three months after its first successful nuclear test. In January 1965, Luo Ruiqing said in a joking fashion to an Indonesian delegation, "[W]e have conducted the explosion of a nuclear bomb. That involved advanced and complicated technology. But exploding a nuclear bomb does not mean that our troops have been equipped with nuclear weapons. Of course, you have not yet requested nuclear weapons from us." ${ }^{75}$

In late July 1965, at a meeting of the 36th Muhammadiyah Congress in Bandung, Sukarno announced, "In the near future we will succeed in making our own atomic bomb. The atomic bomb [is] not going to be used for aggression, but simply to maintain the sovereignty of our motherland in case of harassment or attack." Indonesian journalist Rosihan Anwar recorded Sukarno's announcement in his diary, with added comments: "Has Indonesia already achieved the high level of technological capability to make an atomic bomb? Or has Indonesia received assistance from the PRC, who had just detonated a nuclear bomb? Was the making of the atomic bomb secretly discussed between Subandrio, Zhou Enlai, and Chen Yi during their repeated meetings in the recent months?" ${ }^{76}$ It is possible that discussions on Chinese assistance to Indonesia regarding nuclear technology had been ongoing in the first half of 1965 . And Sukarno probably decided to make the public announcement of Indonesia's nuclear ambition after securing Beijing's support.

When Chen Yi visited Indonesia for the Independence Day celebrations in August 1965, Subandrio's attitude was strikingly different from nine months earlier. Subandrio told Chen Yi:

I only realized recently that it was wrong for Indonesia to sign the Limited Test Ban Treaty in Moscow in 1963 ... [T] [Te only way to avoid nuclear war and to safeguard homeland security is for more Afro-Asian countries to obtain nuclear weapons and to break the monopoly of nuclear technology by the Western imperialists and the Soviet Union. Indonesia is determined to build its own nuclear weapons. And Indonesia hopes that China would provide assistance in that regard, as well as in the realms of economic development and arms. ${ }^{77}$

After Chen Yi expressed his support and encouragement, Subandrio eagerly laid out a plan to send an economic delegation to China for more detailed discussions. ${ }^{78}$ When Chen Yi met with Subandrio again privately a few days later, more explicit assurance was given. When Subandrio brought up the issue of nuclear technology transfer, Chen $\mathrm{Yi}$ said, "We can give you help in this regard. If we do not give you

\footnotetext{
75 "Minutes of the Meeting between the Chief of the PLA General Staff Luo Ruiqing and Delegation of Indonesian Military (on Future Visits, the Possible Chinese Aids of Equipment, and Exchange of Intelligence)," January 24, 1965, Chinese Foreign Ministry Archives, 105-01910-07.

${ }^{76}$ H. Rosihan Anwar, Sukarno, Tentara, PKI: Setiga Kekuasaan sebelum Prahara Politik 1961-1965 (Jakarta: Yayasaan Obor Indonesia, 2006), p. 358.

${ }_{77}$ "Vice Prime Minister Chen Yi's Visit to Indonesia and His Meetings with President Sukarno, and etc.," August 16, 1965, Chinese Foreign Ministry Archives, 105-01324-03.

${ }^{78}$ Ibid.
} 
assistance, we are not your true friend. To our knowledge, you have some foundations. Building a nuclear bomb is not an impossible mission, we can totally build it by ourselves. Both parties can discuss this issue secretly." ${ }^{79}$

In line with the agreement reached in the Chen Yi-Subandrio talks, an Atomic Energy Group affiliated with a sizable Indonesian Economic Delegation arrived in China on September 21, 1965. The Atomic Energy Group was composed of both military personnel and scientists, including Vice Air Marshal Sutopo and the former director of BATAN, Djali Ahimsa. The requests put forward by the group included:

- To visit laboratories and to understand the development of relevant research;

- To visit some chemistry laboratories, including laboratories where analyses on raw materials, such as uranium, take place, to understand the procedure of processing used fuel;

- To see how atomic energy is used for military purposes;

- To visit nuclear reactors that are already in use, including those for research purposes, power supply purposes, and for other purposes; and

- To send staff to conduct research together with the Chinese experts. ${ }^{80}$

According to Djali Ahimsa, the off-the-record purpose of the trip was to receive substantial assistance from China for Indonesia's nuclear project. Most importantly, the group intended to bring back plutonium from China, which was part of the deal between Sukarno and top Chinese leaders. Djali Ahimsa was confident that, with plutonium from China, Indonesian nuclear scientists would be capable of building a nuclear bomb. Meanwhile, the two sides also had tentatively scheduled a visit by Chinese nuclear scientists to Indonesia in 1966 for technical support. Tsinghua University and the Bandung Institute of Technology were discussing the possibility of collaboration in September 1965, but no technical staff from China arrived before G30S took place. ${ }^{81}$

During their stay in Beijing, the Atomic Energy Group visited a research nuclear reactor at Tsinghua University, the nuclear physics laboratories at Peking University, and the No. 1 and No. 2 Institutes of Atomic Energy Research, and had discussions with scientists at all the institutes. The group did not seem to have visited any military nuclear sites. On September 22, Zhou Enlai met with the group and said:

The purpose of this trip was to explore the possibilities of building basic nuclear projects for peaceful use [in Indonesia], for scientific research, industrial production, education, and etc. For a wider range of collaboration, a decision needs to be made between the top leaders of our two countries. Once our party and government make the decision, Vice Prime Minister Chen Yi and I will have

\footnotetext{
79 "Vice Prime Minister Chen Yi's Private Meeting with the Indonesian First Deputy Prime Minister Subandrio," August 21, 1965, Chinese Foreign Ministry Archives, 105-01912-09.

80 "Briefings on Receiving the Atomic Energy Group of the Indonesian Economic Delegation," September 21-September 28, 1965, Chinese Foreign Ministry Archives, 105-01323-02.

${ }^{81}$ Interview with Djali Ahimsa, Jakarta, April 18, 2013.
} 
discussions with President Sukarno when we meet at the Second Afro-Asian Conference. $^{82}$

On the evening of September 30, 1965, just a few hours before G30S took place in Indonesia, Mao Zedong and Liu Shaoqi met with representatives of the delegation of Indonesia People's Consultative Assembly, which was invited to Beijing's National Day celebration. Indonesian politicians present at the meeting included Chairul Saleh, the speaker of the Indonesia People's Consultative Assembly, and Ali Sastramidjojo, the chairman of the PNI. A significant part of the meeting concentrated on nuclear issues.

Chairman Mao: ... Now, the world is not peaceful, so we need military forces and, moreover, the atomic bomb. Do you want to build atomic bomb?

Chairul Saleh: We would love to.

Chairman Mao: You should build one.

Chairul Saleh: We do not agree that nuclear weaponry should be dominated by a few big powers.

Chairman Mao: That's right. Two big countries in the world want to monopolize nuclear power, but we won't listen to them. We still create our own. However, we are currently at the beginning stage. The Americans sent out a message threatening that they will blow up our nuclear reactors. That will be the end of the world. Some people say, reactors can be blown up, but ideals cannot be blown up. Even if the first batch of nuclear reactors were blown up, people with ideals could build a second batch.

Chairul Saleh: Yes, new ones could be built.

Chairman Mao: It was the secretary of defense of the United States who said that.

Chairul Saleh: Modern technology can no longer be monopolized by imperialists.

Chairman Mao: Yes, there should be no monopoly. All [technologies] should be open; all [countries] should be able to communicate [freely].

Chairul Saleh: Therefore we are very happy. Chairman Mao just said that China was only at the beginning stage of nuclear technology development. But for us, China creating its own atomic bomb is an event with great significance. We are greatly encouraged by this event spiritually and materially. This event will further encourage all the New Emerging Forces to build a new world.

Chairman Mao: You have to build up your agriculture and light industry first. And you need to find the raw material to build atomic bomb. Is there any in your country?

82 "Minutes of the Meeting between Prime Minister Zhou Enlai and the Indonesian Economic Delegation," September 22, 1965, Chinese Foreign Ministry Archives, 105-01321-07. The Second Afro-Asian Conference was originally schedule to convene in Algeria in June 1965, but was cancelled due to a coup in the host country. China and Indonesia were discussing postponing the Second Afro-Asian Conference before G30S took place. 
Chairul Saleh: I believe there is. Our current geographical survey has shown some positive signs. Now we are vigorously conducting the survey and making use of the natural resources.

Chairman Mao: Do you have iron mines or coal mines? The resources in your country are richer than those of my country. You have huge amount of petroleum and rubber, both of which are rare in the world.

Chairul Saleh: That is true. Therefore, we sent an economic delegation to China for the purpose of learning from China and fostering closer collaboration between the two countries. Developing iron industry and heavy industry are the most important tasks for Indonesia. We don't have large-scale ironmaking and steelmaking industries. In that aspect, we would be glad to build up these industries as soon as possible, if China is willing to offer us help.

Chairman Mao: This is totally workable. We surely can help you unconditionally. ${ }^{83}$

There is ambiguity in the sphere in which Mao offered "unconditional" support to Indonesia. In the context of the conversation, Mao's offer could be interpreted either narrowly (steel industry) or broadly (which would include nuclear assistance). The fact that Mao openly espoused the idea of a nuclearized Indonesia shortly before the coup took place is both significant and perplexing. Given Mao's sometimes highly unpredictable personal style in his conversations with foreign guests, it is very difficult to understand what exactly he meant and for what purpose he chose to bring up such a sensitive topic at such a sensitive time. (While there is no evidence that China played a significant role in the planning of G30S, top Chinese leaders knew in advance of Aidit's plan, as I describe later.)

What is certain, however, is that G30S fundamentally changed the course of Sukarno's quest for nuclear power, as well as China's potential assistance to Indonesia. Zhou Enlai originally planned to have a more extensive conversation with the Atomic Energy Group on October 2, 1965, to discuss the details of Chinese assistance to Indonesia. ${ }^{84}$ However, due to the political changes in Indonesia, the official meeting was relocated to Zhou Enlai's private residence inside the Forbidden City. Zhou told the group members to wait and see what developed in their country in the wake of G30S. When Djali Ahimsa asked about the possibility of visiting a uranium enrichment plant in Chengdu in southwest China, Zhou said he would try to make the arrangements. But there was no follow-up on this request. ${ }^{85}$

\section{Chinese Medical Aids to Sukarno}

Besides military and nuclear aid, the PRC had also been providing medical aid to the Indonesian president in the early 1960s. Documents from China suggest that Sukarno's physical condition in 1965 was not as bad as some Western scholars

\footnotetext{
83 "Minutes of Chairman Mao Zedong and Chairman Liu Shaoqi's Meeting with the Indonesian Delegation," September 30, 1965, Chinese Foreign Ministry Archives, 105-01917-02.

84 "Minutes of the Meeting between Prime Minister Zhou Enlai and the Indonesian Economic Delegation," September 22, 1965, Chinese Foreign Ministry Archives, 105-01321-07.

${ }^{85}$ Interview with Djali Ahimsa, April 18, 2013, Jakarta.
} 
speculated. Neither Beijing nor the PKI saw Sukarno's death as imminent before G30S. Sukarno probably had been seeing Chinese doctors since the early 1960s. During a meeting between the Indonesian ambassador to China, Sukarni, and Chinese Foreign Minister and Deputy Prime Minister Chen Yi in December 1961, Sukarni said that "Sukarno has been hiding from the United States that he sought help from China for his health issues. But now the United States already knows about it, and has protested." ${ }^{\prime 66}$ The most intensive and highly controversial Chinese medical aid took place between November 1964 and September 1965, when a high-profile Chinese medical team provided Sukarno with diagnosis, prescriptions, and Chinese medical treatments, such as acupuncture and herbal medicine. ${ }^{87}$

Beijing started to provide systematic medical care to the Indonesian president when reports and rumors of Sukarno's deteriorating health started to circulate widely in the West in late 1964. By the end of October 1964, the Chinese ambassador to Indonesia, Yao Zhongming, reported back to Beijing that "the Western media has been reporting on the possible stepping down of Sukarno due to his health issues. However, there has not been any discussion in the Indonesian media. Neither was this issue mentioned by our friends [i.e., the PKI]." ${ }^{88}$ Sukarno's health information was disclosed secretly to media by doctors in Vienna, who discovered stones in the president's right kidney and determined that he would die within the next three months if these stones were not removed via surgery. In November 1964, a Chinese medical team headed by renowned urologist Dr. Wu Jieping arrived in Indonesia and carried out a thorough medical examination on Sukarno. The Chinese medical team disagreed with the diagnosis from Vienna, claiming that it was cardiovascular problems, rather than kidney stones, that needed immediate attention. The treatment program the Chinese medical team designed for Sukarno proved to be highly effective. And the team left Indonesia in early January 1965, after Sukarno's condition stabilized. ${ }^{89}$

In the months between winter 1964 and spring 1965, the improvement in Sukarno's health strengthened his trust and confidence in the Chinese medical team, which became his regular health provider between early 1965 and the outbreak of G30S. Sukarno found the Vienna doctors' suggestions that he undergo surgery highly disagreeable and even unacceptable. He was delighted that the Chinese medical team was right-he did not need to have surgery for his kidney stones. Moreover, in April 1965, Sukarno discovered that his health information had been leaked to the Western media by the doctors in Vienna. ${ }^{90}$ Thus, in both technical and political terms, the Chinese medical team became the most reliable choice for the Indonesian president.

\footnotetext{
86 "An Extract of the Report on Vice Prime Minister Chen Yi's Meeting with Indonesian Ambassador to China, Sukarni," December 22, 1961, Chinese Foreign Ministry Archives, 105-01768-04.

${ }^{87}$ Sukarno seemed to have a strong preference for a kind of capsule made of Chinese herbal medicine. He tended to overdose slightly (the prescription was five capsules per time, but Sukarno took six instead), which upset the Chinese doctors. "Prescriptions for Sukarno," April 23, 1965, Chinese Foreign Ministry Archives, 105-01331-01.

88 "On a Possible Coup in Indonesia," October 30-December 20, 1964, Chinese Foreign Ministry Archives, 105-01233-06.

89 "Our Medical Team's Treatment for Sukarno and President Sukarno's Health Conditions," November 24, 1964, Chinese Foreign Ministry Archives, 105-01234-01.

90 "Prescriptions for Sukarno," April 23, 1965, Chinese Foreign Ministry Archives, 105-01331-01.
} 
The Chinese medical team treated Sukarno when he suffered a severe cerebral vasospasm attack in August 1965, which caused much commotion on the Indonesian political scene and was said to have led to the escalation of tensions before G30S. On the morning of August 4, Sukarno felt dizzy after he got up, and the vertigo became incapacitating after 8:00 AM, accompanied by symptoms such as nausea, vomiting, and sweating. At 10:00 AM, the Chinese medical team was summoned to the Presidential Palace. In its first report back to Beijing, the Chinese medical team wrote, "As for now, it remains unclear whether the president's condition will deteriorate. Now we are giving him treatments, and there has been no sign that the president will be paralyzed. Please inform Aidit." ${ }^{\prime 1}$ In a telegram dispatched a few hours later, the medical team wrote, "[W]e have diagnosed Sukarno as suffering from Meniere's disease. As for now, there has not yet been thrombus forming due to cerebral hemorrhage. We expect a gradual recovery in short term, but we also need to be alert about possible thrombus formation and related complications in his heart and kidney." The medical team requested Beijing to send a neurologist from China for a more detailed diagnosis. ${ }^{92}$

Sukarno's sudden illness was extremely alarming to the Chinese leadership. On the morning of August 5, the Chinese Foreign Ministry instructed Ambassador Yao Zhongming to visit Sukarno, to pay close attention to any developments regarding his condition, and to "report back to the Foreign Ministry at all times." At 1:30 PM the same day, Zhou Enlai instructed the Ministry of Health to study carefully the reports on Sukarno's condition that the Chinese medical team had wired from Jakarta the day before, to prepare the needed medicines, and to select two of the country's best neurologists, who would fly to Jakarta together with PKI chairman Aidit the very next day. At the time Aidit was visiting Beijing and was originally scheduled to travel from Beijing to Hanoi on August 7. After being informed by Zhou Enlai about Sukarno's condition, Aidit decided to cancel his trip to Vietnam and returned to Indonesia on August $6 .{ }^{93}$

On the evening of August 5, after the arrangements for Aidit's return trip had been settled, the Chinese Foreign Ministry received relieving news from Jakarta: the Chinese medical team reported that Sukarno's condition had significantly improved since morning, and he was "able to talk and laugh as usual and to have his breakfast." The Chinese medical team decided that the cerebral vasospasm attack was over, and there should be no long-term sequela. As for the future prospects of the president's health, the Chinese doctors were not optimistic. "[T]his attack reveals that arteriosclerosis [has] affected his whole body, including heart, kidney, and brain. His long-term health condition is worrisome." ${ }^{\prime 4}$

Despite the Chinese doctors concerns, Sukarno himself seemed confident that he had fully recovered and soon resumed working. It seems to have been a strategic decision, given that the president's health issues had become a sensitive topic amid an already tense political atmosphere in Indonesia. On August 6, Sukarno told the

\footnotetext{
91 "On President Sukarno's Brain Illness," August 4, 1965, Chinese Foreign Ministry Archives, 105-01331-01.

92 "Conditions of President Sukarno's Illness," August 4, 1965, Chinese Foreign Ministry Archives, 105-01330-01.

93 "President Sukarno's Conditions Improved on the 5th," August 5, 1965, Chinese Foreign Ministry Archives, 105-01330-01.

${ }^{94}$ Ibid.
} 
Chinese doctors that he felt no discomfort and was ready to continue his preparation for the Independence Day speech. On August 9, Sukarno fully went back to his daily routines. On August 15, Chen Yi, who was invited to Jakarta for Indonesia's Independence Day celebrations, met with Sukarno. During the meeting, Chen Yi asked Sukarno to pay keen attention to his health, suggesting that Sukarno could ask someone to read the Independence Day speech for him if needed. ${ }^{95}$ But Sukarno gave the speech himself on August 17 in order to avoid upheaval in the political scene. Chen Yi's Indonesian interpreter, Huang Shuhai, who was at the Independence Day celebrations, observed that Sukarno appeared to be healthy and energetic while giving the speech and hosting Chen $\mathrm{Yi}^{96}$

Notwithstanding these improvements, the Chinese medical team was frustrated with Sukarno's refusal to switch to a healthier life style. Since Sukarno's cerebral vasospasm attack was triggered by "mood swings caused by domestic conflicts," the Chinese doctors advised Sukarno to "reduce his workload and exercise restraint in his sex life." ${ }^{97}$ But this advice fell on deaf ears. On August 20, the medical team reported that Sukarno "had the same old attitude towards medication and sex ... [S]ince the afternoon of August 16, he had stopped taking tranquilizers and antihypertensive drugs himself." The Chinese medical team decided to leave Indonesia as long as this uncooperative patient's condition continued to stabilize. ${ }^{98}$

The medical team's decision to leave Indonesia was probably also affected by Beijing's concerns regarding the political implications of the presence of Chinese doctors by the side of the Indonesian president at such a critical time. When the Chinese medical team was dealing with Sukarno's sudden illness in early August, the Foreign Ministry emphasized that "we should let Sukarno's own doctors, Dr. Suharto and Dr. Lauw Ing Tjhiong, take charge. We can play an assisting role if we have the consent from Sukarno himself." 99 Yet, overall, Beijing's medical aid to Sukarno made itself highly susceptible to suspicions and accusations. In the 1990s, a Chinese language magazine based in Hong Kong claimed that Zhou Enlai took Wu's mistaken diagnosis and thought Sukarno's health conditions were so critical that his life could end at any moment. Zhou relayed his fears to Aidit, who then decided to take preemptive action against the Indonesian Army. Dr. Wu regarded these accusations as "ridiculous." As he put it, "I have never made such reports to Zhou Enlai. Sukarno's health conditions were not as bad as in some rumors. His life span proved this point. I can only ignore these slanders." ${ }^{100}$

\footnotetext{
"5/"Vice Prime Minister Chen Yi's Visit to Indonesia and His Meetings with President Sukarno, and etc.," August 16, 1965, Chinese Foreign Ministry Archives, 105-01324-03.

${ }^{96}$ Interview with Huang Shuhai, Beijing, July 17, 2009.

97 "President Sukarno's Illness and Our Medical Team's Treatment for Him," August 5, 1965.

98 "President Sukarno's Illness and Our Medical Team's Treatment for Him," August 20, 1965, Chinese Foreign Ministry Archives, 105-01330-01.

99 “President Sukarno's IIIness and our Medical Team's Treatment for Him," August 5, 1965.

${ }^{100}$ Deng Li, Wu Jieping zhuan [A Biography of Wu Jieping] (Hangzhou: Zhejiang renmin chubanshe, 1999). Quoted in Zhou Nanjing and Kong Zhiyuan, eds., Sujianuo zhongguo yindunixiya huaren [Sukarno, China and the Chinese Minority in Indonesia] (Hong Kong: Hong Kong Social Science Press, 2003), pp. 419-40.
} 


\section{Connections between the Chinese and Indonesian Communist Parties}

Beijing can be proven to have reached out to Indonesia with offers of small arms, nuclear materials and technology, and medical care for the president, and it is reasonable also to raise the question of whether the Chinese leadership helped its Indonesian comrades design the plans for G30S. As the paragraphs below suggest, the Chinese leaders were aware of the PKI's plan to prevent the anti-communist army generals from making a move to seize power. But Beijing remained aloof from the actual planning of G30S.

As early as mid-1963, the top Chinese leaders perceived the situation in Indonesia to be full of tension and ripe for a power transition. In the words of Zhou Enlai, in Indonesia the most critical issue was that:

[N]asution, with the support from the United States and Chiang Kai-shek's government in Taiwan, is trying by all means to overthrow Sukarno and replace him. This is a life-and-death struggle, which will continue. No matter what Sukarno's attitude is, [the Indonesian revolution] will be born. In this new era in the history of Indonesia's struggle against imperialism and feudalism, new configurations of power will occur. The speed things evolve depends on the relative power of the PKI and its strategies. [I] believe that the PKI has foresight and will be prepared. ${ }^{101}$

On August 5, 1965, Aidit, his wife Tanti, and Jusuf Aditorop, the deputy party secretary of the PKI, had a meeting in Beijing with Mao Zedong and other top Chinese leaders, including Liu Shaoqi, Zhou Enlai, Deng Xiaoping, Peng Zhen, and Chen Yi. During the meeting, Zhou reported to Mao about Sukarno's poor health (he had suffered a severe cerebral vasospasm attack the day before), and discussed the revised travel arrangements for Aidit's early return to Indonesia. Subsequently, both sides talked about the Indonesian Army:

Mao: I think the Indonesian right wing is determined to seize power. Are you determined, too?

Aidit: [Nods] If Sukarno dies, it would be a question of who gains the upper hand.

Mao: I suggest that you should not go abroad so often. You can let the Number Two person (i.e., your deputy) [in your party] go abroad instead.

Aidit: For the right wing, they could take two possible kinds of actions: First, they could attack us. If they do so, we would have reasons to counterattack. Second, they could adopt a more moderate method by building a Nasakom government. Without Sukarno, it would be easy for the right wing to win the support of those who are in the middle in order to isolate us. The latter scenario would be difficult for us. However, no matter what, we have to deal with them. The United States advised Nasution not to initiate a coup. This is because if he

101 "On the Self-defense and Self-protection during the Anti-Chinese Riots in Indonesia, and the Deployment of Contingency Measures of Our Embassy in Indonesia," June 23, 1963, Chinese Foreign Ministry Archives, 105-01826-03. 
initiates a coup, the left wing would also take the same course of action. The Americans told Nasution that he should wait patiently; even if Sukarno dies, he [Nasution] should be flexible rather than [initiate] a coup. He accepted the suggestion from the Americans.

Mao: That is unreliable. The current situation has changed.

Aidit: In the first scenario, we plan to establish a military committee. The majority of that committee would be left wing, but it should also include some middle elements. In this way, we could confuse our enemies. Our enemies would be uncertain about the nature of this committee, and therefore the military commanders who are sympathetic to the right wing will not oppose us immediately. If we show our red flag right away, they will oppose us right away. The head of this military committee would be an underground member of our party, but he would identify himself as [being] neutral. This military committee should not last for too long. Otherwise, good people will turn [into] bad people. After it has been established, we need to arm the workers and peasants in a timely fashion. ${ }^{1112}$

In the record of the meeting quoted above, Mao shifted the conversation to his own experience at the Chongqing Negotiations with the Chinese Nationalist Party. Given the historical background of the Chinese Civil War, Mao might have been making an oblique suggestion that Aidit should be prepared for both peace talks and armed struggles. Though the Chinese leadership's attitude remained unclear, it is evident that Beijing was informed of Aidit's plan, and at least did not object to it.

It is unlikely, however, that Beijing knew of the exact timing of G30S or participated in the planning. Indeed, October 1, 1965, probably was a nerve-racking day for the Chinese leaders, who had to maintain their composure at the PRC's National Day celebrations despite the drastic changes in the situation in Indonesia. The first piece of news about G30S came to Beijing from the foreign media rather than from the Chinese embassy in Jakarta. Apparently, Beijing sent a telegram to its embassy in Jakarta right after receiving the news, requesting clarifications. Yet a reply did not reach Beijing until more than a day later. ${ }^{103}$ In other words, in the first twenty-four hours after G30S took place, Beijing completely lost contact with its embassy in Jakarta. The Associated Press, Agence France-Presse, and Reuters were the only sources Beijing had available. During his first official meeting with the Indonesian guests after G30S, Zhou Enlai told Chairul Saleh, Ali Sastroamidjojo, General Wylyo Puspoyudo, and Ambassador (to China) Djawoto that "we have recently received several pieces of news reports from abroad. According to these reports, a Council of Generals staged an abortive coup, and the Guards of the Presidential Palace captured those involved ...

\footnotetext{
102 "Chairman Mao meets the delegation of the PKI," Chinese Communist Party Central Archives, August 5, 1965.

103 "Minutes of the Meeting with Prime Minister Zhou Enlai and the Delegation of the Staff College of the Indonesian Air Force," October 3, 1965, Chinese Foreign Ministry Archives, 105-01687-02. Zhou told the delegation of the Staff College of the Indonesian Air Force: "[W]e sent a telegram to our embassy in Jakarta the day before yesterday, but we have not received a reply yet." Yet in his talk with Chairul Saleh, he said some telegrams went through on October 2, 1965. See "Minutes of Prime Minister Zhou Enlai's Second and Third Meeting with the Delegation of Indonesia People's Consultative Assembly (on the Domestic Situation in Indonesian and the Afro-Asian Conference)," October 1-4, 1965, Chinese Foreign Ministry Archives, 105-01917-01.
} 
The President is safe. And the Guards of the Presidential Palace formed a 'Revolutionary Council' to take control of the situation." On October 2, some telegrams finally went through between Beijing and Jakarta, including one from the Chinese Embassy confirming the safety of Sukarno. However, communication remained intermittent and the radio signals from the Chinese embassy were constantly disrupted. The New China News Agency's (Xinhua) Jakarta office was completely blocked. ${ }^{104}$

In his talk with Chairul Saleh on October 1, Zhou's interpretation of the role of the Revolutionary Council as responding to the attempted coup by the Council of Generals, rather than initiating G30S by itself, was intriguing. In a meeting in mid-November with North Korean Prime Minister, Ri Ju-yeon, Chen Yi said that the leader of G30S, Untung, "was following Sukarno's instructions." He further explained: "There were supporters of Sukarno as well as spies from the army and right wing within the PKI. Sukarno's supporters and PKI members were inside the army, too. It is difficult to understand what was going on." ${ }^{105}$ Given that both Zhou Enlai and Chen Yi were present at Aidit's discussions with Mao on August 5, the two top Chinese leaders could be trying to protect the PKI as well as the CCP itself by hiding the fact that Beijing was informed of Aidit's plan ahead of time. It is also possible, perhaps probable, that the Chinese leadership was surprised by the swiftness of the PKI's actions. Beijing might have been expecting a longer period of Sukarno-PKI collaboration, which would allow the PKI to buy more time for full-scale militarization. Thus, the way in which the PKI rushed to action probably had already made the situation look worrisome to Beijing. On October 2, the foreign policy-making circle in Beijing had already learned that the Revolutionary Council had failed, and Suharto had taken control of the situation. ${ }^{106}$

It seems that from the immediate aftermath of G30S to late October 1965, Chinese leaders were still hoping for the emergence of a progressive, left-leaning government, which would continue to rely on an alliance between Sukarno and the PKI. Beijing was cherishing high expectations for Sukarno to emerge as the game-changer. On October 3, when meeting with the delegation of the Staff College of the Indonesian Air Force, Zhou said he was relieved to hear President Sukarno's own voice in the broadcast at 2:30 PM on that day. By the end of the conversation, Zhou told the head of the delegation, "Please tell President Sukarno to take good care of his health for the sake of Indonesia's revolution." ${ }^{107}$ On October 4, before Chairul Saleh set off for Jakarta, Zhou asked Chairul Saleh to convey the regards of the leaders of the Chinese Communist Party and the government, including Mao Zedong, Liu Shaoqi, Zhu De, Chen Yi, Peng

\footnotetext{
${ }^{104}$ Minutes of Prime Minister Zhou Enlai's Second and Third Meeting with the Delegation of Indonesia People's Consultative Assembly (on the Domestic Situation in Indonesian and the Afro-Asian Conference)," October 1-4, 1965, Chinese Foreign Ministry Archives, 105-01917-01.

105 "Prime Minister Zhou Enlai, Vice Prime Minister Chen Yi's Second Meeting with the Vice Prime Minister of North Korea," November 11, 1965, Chinese Foreign Ministry Archives, 106-01476-06.

106 "On the 30 September Movement in Indonesia," October 2, 1965, Chinese Foreign Ministry Archives, 204-01389-04.

${ }^{107}$ Minutes of the Meeting with Prime Minister Zhou Enlai and the Delegation of the Staff College of the Indonesian Air Force," October 3, 1965, Chinese Foreign Ministry Archives, 105-01687-02.
} 
Zhen, and himself, to Sukarno. Zhou said that "all of us have been listening to news about the situation in Indonesia from October 1 to October 3." 108

Yet such friendly gestures took a sharp turn when conflicts broke out between staff members of the Chinese Embassy and the Indonesian Army at the PRC Embassy compound in Jakarta, due to the former's refusal to lower the Chinese national flag to half-mast on the national memorial day to commemorate the army generals killed in G30S. The clash was followed by the Indonesian military's search of the dormitory used by Chinese Embassy staff and the residence of Chinese engineers at the construction site of the Beijing-sponsored CONEFO building. ${ }^{109}$ In the eyes of the Chinese leaders, Sukarno's failure to protect China's interests this time was a dealbreaker, reflecting Sukarno's lack of both credibility and political prowess in the fastchanging political scene in Indonesia. Chen Yi said to the visiting North Korean prime minister, Ri Ju-yeon, in mid-November:

Sukarno wanted to mediate and then take control of the situation, but the leeway he had [was] extremely limited. From 1955 to the present, we have been collaborating with Sukarno for more than a decade. Our policy towards Sukarno has made a great impact among countries in Asia and Africa. We told him that he could use attacks on and searches in our commercial office, the Chinese experts' residence (referring to the Chinese engineers sent to Indonesia for the CONEFO building project), and consulates as a card to negotiate with the army and the right wing. He can win support from them. He is grateful.

Zhou Enlai said at the same occasion:

[W]e believe Sukarno and Subandrio are devoted to maintaining friendly relations with China ... but the right wing wanted to destroy bilateral relations completely. The ethnic Chinese were also persecuted, suffering from robbery and illegal detention. Sukarno hopes that we will give him some more time. But time has passed already. He could only shake his head and sigh ... [I]t is difficult to say how much Sukarno can do. I don't think he has much leverage.

Zhou further quoted King Sihanouk, who was living in exile in Beijing at the time:

King Sihanouk admits that the right wing is taking control of the situation in Indonesia, although they had no solid foundation of support among the people. But Sihanouk trusted Sukarno too much. He thinks Sukarno is able to overturn the situation. This is not accurate. ${ }^{110}$

Deeply disappointed with Sukarno, Beijing began to expect a full-fledged communist revolution in Indonesia beginning mid-November 1965. As Chen Yi put it bluntly in his conversation with Ri Ju-yeon: "Personally, I think it will be a good thing if Sukarno is overthrown. Sukarno could mediate between the right and the left. But

\footnotetext{
108 "Minutes of Prime Minister Zhou Enlai's Second and Third Meeting with the Delegation of Indonesia People's Consultative Assembly (on the Domestic Situation in Indonesian and the Afro-Asian conference)," October 1-4, 1965.

109 "Chinese Government Strongly Protests against the Indonesian Army's Violation of Diplomatic Protocols," Renmin ribao [People's Daily], October 19, 1965.

110 "Prime Minister Zhou Enlai, Vice Prime Minister Chen Yi's Second Meeting with the Vice Prime Minister of North Korea," November 11, 1965, Chinese Foreign Ministry Archives, 106-01476-06.
} 
the future of Indonesia depends on the armed struggle of the PKI. This is the most important thing. It is definitive." ${ }^{111}$ However, at the time, Beijing had no clear picture of the situations in Central and East Java, and Sumatra, where communist forces were believed to be the strongest. All direct communications between the PKI and the CCP had been cut off. Beijing was not able to receive any information directly from the PKI, or indirectly from North Korean or North Vietnamese embassies in Jakarta. There were PKI members coming to China from Jakarta, but the number seemed small and none of them had reliable information about the conditions outside of the capital. The Chinese leadership knew that there was an armed force of more than ten thousand in Central Java. And Beijing was confident that the PKI was building up its strength and had a good chance in the final showdown with the army because the party was believed to have control over the vast countryside and mountainous regions. Chen Yi strongly endorsed the PKI's armed struggle:

The PKI was most resolute in its anti-imperialist, anti-revisionist campaigns. It can definitely withstand this test. Obviously, the united front is not doing the PKI any good. The PKI should resolutely shift its policy to armed struggle ... An overall revolution is inevitable in Indonesia. No matter what actions the United States and the right-wing forces will take, no matter what tricks Sukarno will play, fundamental issues need to be resolved. Indonesia is now at the eye of a storm, at the eve of a great revolution. ${ }^{112}$

With regard to China's response to the radical change in Indonesian domestic politics and subsequently in bilateral relations, Chen Yi and Zhou Enlai seemed to have different stances, as shown in their conversations with North Korea's prime minister in mid-November 1965. Chen Yi's position was more aggressive, as he announced that China would not serve as a mediator in Indonesian politics. He claimed: "It would serve us the best if our ambassador is expelled, which indicates that there is hope for Indonesia's revolution. I hope the conflicts between the right wing and left wing will escalate." ${ }^{113}$ Zhou Enlai, on the other hand, was more cautious and diplomatic. He made a clear distinction between the two parts of the Chinese policyone on state-to-state relations, the other towards the Indonesian revolution. For bilateral relations, Zhou said Beijing would continue to work with Sukarno as long as he was sincere, while continuing its strong protest against the army and other antiChina right-wing groups. For intra-communist-party relations, Zhou said: "We support our fraternal party [the PKI], but our support is within proper boundaries. It is the Indonesian people's revolution, led by the Indonesian left-wing. We cannot surpass them. Now the PKI has not yet made any public announcement. Therefore we cannot speak on its behalf." ${ }^{\prime 114}$

The Chinese leadership's great expectations were soon shattered. In December 1965, when Mao learned of the death of Aidit, who was gunned down in Central Java by Suharto's troops, he wrote a poem:

\footnotetext{
${ }^{111}$ Ibid.

112 Ibid.

${ }^{113}$ Ibid.

${ }^{114}$ Ibid.
} 
Sparse branches stood in front of my windows in winter, smiling before hundreds of flowers

Regretfully those smiles withered when spring came

There is no need to grieve over the withered

To each flower there is a season to wither, as well a season to blossom

There will be more flowers in the coming year. ${ }^{115}$

The poem showed Mao's confidence for a revival of the communist movement in Indonesia. However, with Mao launching the Great Proletarian Cultural Revolution while Suharto solidified his grips on political power through a cleansing of communists in Indonesia, bilateral relations plummeted to an extreme low. In the spring of 1966, Beijing started to openly oppose the Suharto regime after a right-wing students' group and the Indonesian Army attacked the Chinese Embassy in April. Radio Peking's constant broadcasts of fierce protests aimed towards an Indonesian audience escalated the tension and, ironically, granted the Indonesian Army the opportunity to further extend its accusations that Beijing was involved in G30S. ${ }^{116}$

The Suharto regime also accused Beijing of maintaining its connection with the PKI after G30S by secretly offering shelter to PKI exiles. It is true that Beijing did make living arrangements for PKI members and affiliates who were in China when G30S took place, and those who later came to China from abroad seeking sanctuary, including PKI leader Jusuf Adjitorop and Aidit's daughter Ibarruri and brother Asahan Sobron. ${ }^{117}$ Because the timing of G30S coincided with the PRC's National Day celebrations, approximately 4,500 Indonesian visitors from various delegations (political, economic, military, and cultural) were in different parts of China at the time of G30S. In Beijing alone, there were twenty-eight groups totalling almost five hundred people altogether. As Zhou Enlai said to Chairul Saleh on September 30, 1965 , before the start of a national banquet, "You [Indonesian guests] will take up the largest percentage in the banquet hall tonight. I wish we could have Indonesianspeaking staff to attend to you at each and every table." ${ }^{118}$ After G30S, the PRC adopted a generous policy towards the Indonesian visitors. On October 4, Zhou Enlai said to the delegation of the Indonesia People's Consultative Assembly, "It is difficult to find convenient ways of transportation in such a short time for so many people. We are willing to receive anyone who cannot leave immediately and provide any

\footnotetext{
${ }^{115}$ Mao, "Pusuanzi dao guoji gongchanzhuyi zhanshi aidi tongzhi" (In Memory of Comrade Aidit, an International Communist Fighter), December 1965, http:/ / cpc.people.com.cn/ GB/ 69112/70190/70199/ 4763391.html, accessed July 20, 2008.

116 "Awas Neo-imperialisme Kuning," April 25, 1965, Angkatan Bersendjata. This editorial accused the PRC of being a "new yellow imperialist" that interfered with Indonesian domestic politics, particularly through the unfriendly and insulting reports by New China News Agency (Xinhua) and Radio Peking.

${ }^{117}$ Ibarruri has written about her experience in China in Ibarruri Putri Alam, Roman biografis Putri Alam, anak sulung D. N. Aidit (Jakarta: Hasta Mitra, 2006). For an analysis of this book, see David T. Hill, "Writing Lives in Exile: Autobiographies of the Indonesian Left Aboard," in Locating Life Stories: Beyond East-West Binaries in (Auto)Biographical Studies, ed. Maureen Perkins ( Honolulu, HI: University of Hawaii Press, 2012), pp. 215-36.

118 "Minutes of Prime Minister Zhou Enlai's First Meeting with the Delegation of Indonesia People's Consultative Assembly (on the Domestic Situation in Indonesian and the Afro-Asian Conference)," September 30, 1965, Chinese Foreign Ministry Archives, 105-01917-03.
} 
kind of amenity possible. If you want to travel in China, you are free to do so; if you want to leave, you are free to do so as well. We are willing to help in both cases." ${ }^{119}$

Among the Indonesian visitors, only a small number (mostly high-ranking government officials) were able to leave for Indonesia shortly after G30S, while a larger portion stayed in China for a more extended period of time. On October 2, the Indonesian Air Force sent a plane from Halim Airbase to Beijing to pick up some delegates. ${ }^{120}$ Vice Air Marshal Sutopo and nuclear scientist Djali Ahimsa were on board, and they arrived in Indonesia on October $6 .{ }^{121}$ At the same time, however, the PKI members and sympathizers who were not able or not willing to leave for Indonesia were taken care of by the CCP. According to playwright and PKI member Utuy Tatang, who stayed in China between 1965 and 1974, those who had health concerns were mostly transferred to hospitals in Guangzhou, and later to a sanatorium in South China. ${ }^{122}$ The healthy or recovered visitors who wished to stay were relocated to the Nanjing Military Academy, where they were drilled in Cultural Revolution propaganda and forced to carry on meetings for criticism and self-criticism, and attend study sessions on the works of Mao Zedong every day. ${ }^{123}$ Some witnesses mentioned that the PKI exiles received training on guerrilla-warfare strategies at the Nanjing Military Academy. ${ }^{124}$ However, there are few written sources that can either confirm the existence of such training programs or inform us about its beginning and ending dates. It is likely that the Chinese government stopped the training in 1968 or 1969, when it became clear that the nascent armed struggles in South Blitar and Kalimantan had ended and the remaining PKI members had been decimated.

Most importantly, during the Cultural Revolution the exiles were instructed to

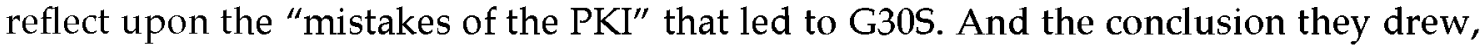
which was probably an attempt to cater to the radicalized political atmosphere in China at the time, was that the PKI had sown the seeds for its own destruction ever since it made the decision to give up armed struggle. The parliamentary road, with which the PKI had been achieving great success, was thus regarded as revisionist and a

\footnotetext{
119 "Minutes of Prime Minister Zhou Enlai's Second and Third Meeting with the Delegation of Indonesia People's Consultative Assembly (on the domestic situation in Indonesia and the Afro-Asian conference)," October 1-4, 1965, Chinese Foreign Ministry Archives, 105-01917-01.

120 "Minutes of the Meeting with Prime Minister Zhou Enlai and the Delegation of the Staff College of the Indonesian Air Force," October 3, 1965, Chinese Foreign Ministry Archives, 105-01687-02.

${ }^{121}$ Interview with Djali Ahimsa, Jakarta, April 18, 2013.

${ }^{122}$ Utuy Tatang, Di Bawah Langit Tak Terbintang (Jakarta, Pustaka Jaya, 2001), pp. 77-104. The sanatorium in South China that Utuy Tatang mentioned might be the guesthouse for Southeast Asian communist exiles located in Nanchang, Jiangxi Province. Interview with Suar Suroso, Nanchang, China, October 9, 2013. Suar Suroso, the former secretary of the PKI's youth organization, Pemuda Rakyat, arrived in Beijing from Moscow in 1967. The international branch of the CCP made arrangements for Suar Suroso and his family to settle in Nanchang.

${ }^{123}$ Ibid., pp. 91-97. Utuy Tatang did not mention the name of "Nanjing Military Academy" explicitly, but he wrote that the city was commonly known as the fireplace, or "tungku" of China (a nickname of Nanjing commonly known by the Chinese), and the place that was guarded by the Chinese military, with almost all Indonesian exiles dressed in Chinese military uniform. This deduction is supported by my interview with Adam Wong (Wang Jinming), Hong Kong, September 16, 2013.

${ }^{124}$ Interview with Adam Wong. Adam Wong was one of the "41 patriotic ethnic Chinese youth" who were engaged in conflicts with the army and local police in Medan. In early 1967, he and other "little overseas Chinese heroes" gave talks all around China (via arrangement by the International Branch of the CCP), including the Nanjing Military Academy.
} 
fatal choice. ${ }^{125}$ Adam Wong (Wang Jinming), an ethnic Chinese who returned from Medan to China in 1966, visited the Nanjing Military Academy in early 1967. According to him, there were around one hundred PKI members residing there, and almost everyone was eager to know about the situation in Indonesia and had "endless questions" regarding the cleansing of the PKI. Wong observed that the exiles, who were drawn deeply into the Cultural Revolution, broke into different political factions-there were those who were still loyal to Aidit, and those who had turned against Aidit, either because they bought the argument about the "revisionist nature" of the parliamentary road, or because they blamed Aidit's recklessness for PKI's fall. Following the call to "speak out freely" and to "air one's views fully" during the Cultural Revolution, the two sides both wrote "big-character posters" and held heated debates. ${ }^{126}$

The Chinese government changed its policy towards the PKI exiles in the late 1980s, when Beijing sought to normalize its relations with Jakarta. The official status granted to the PKI exiles was downgraded from "foreign guests of the Party" - a prestigious title in the Chinese context-to "residents of foreign origins." Those who remained in China were given Chinese passports and national identity cards, and assigned to jobs in the civil sector. ${ }^{127}$ When Qian Qichen, the Chinese foreign minister at the time, met with Indonesian State Minister Murdiono for an ice-breaking talk in 1989, Qian explained China's position this way:

We had noticed that Indonesia was particularly concerned about non-interference in the internal affairs of other countries. I stressed that China had no connection with the Indonesian Communist Party-we did not even know whether there was such a party today. There had once been some Indonesians living in China, but most of them had left and probably only a few dozen remained. Some of these had retired; others were employed. We did not allow Indonesians living in China to engage in political activities. ${ }^{128}$

\section{Conclusion}

From late 1964 to September 1965, Beijing used much of its political leverage to push for a scenario that suited its best interests in Indonesia-an adamant leftist government led by Sukarno and the PKI jointly, with the right wing undermined or eliminated. By offering military aid and the promise of nuclear-technology transfers, the PRC was hoping to take advantage of Sukarno's Konfrontasi with the Federation of Malaya and his eager pursuit of nuclear weapons. Ultimately, the Chinese leadership wanted to rally Sukarno's support for Beijing's efforts to weaken Western influence in Southeast Asia and the Pacific. Beijing supported the proposal of the Fifth Force in order to help the pro-Sukarno forces (the PKI and the Indonesian Air Force) strengthen themselves against the right-wing elements in the Indonesian Army. And by offering

\footnotetext{
${ }^{125}$ Utuy Tatang, Di Bawah Langit Tak Terbintang, p. 94.

${ }^{126}$ Interview with Adam Wong.

${ }^{127}$ Interview with Suar Suroso, Nanchang, China, October 10 and 12, 2013. After the Cultural Revolution ended in 1976, Suar Suroso was assigned to teach at a local university, and his wife, who was trained in medicine, at a local hospital.

${ }^{128}$ Qian Qichen, Ten Episodes in China's Diplomacy (New York, NY: Harper Collins, 2005), pp. 93-94.
} 
medical support to Sukarno, the PRC was able to monitor the president's healthSukarno's condition became highly politicized before G30S-and to update the top PKI leaders with the most timely and precise information in this regard. Beijing was informed of Aidit's clandestine plan for G30S in advance, and most probably acquiesced to it. In the aftermath of G30S and during the Cultural Revolution, the CCP offered PKI exiles shelter and the means to make a living.

Beijing's actual impact on political developments in Indonesia in 1965 was very limited, however. The small arms the Chinese leaders offered to Sukarno for the Fifth Force had not arrived prior to G30S. The plan to transfer nuclear materials and technology was disrupted by G30S and never materialized. Sukarno's illness, persistent but not critical, did not directly trigger G30S. From late 1964 to early 1965, Aidit was probably making preparations for a political scenario without Sukarno. But immediately before G30S, it seems most likely that some concerns other than the impending death of Sukarno pushed Aidit into action. Most importantly, Mao was not "the architect of the coup." A clandestine group within the PKI independently made the plan, which was then shared by Aidit with the top Chinese leaders in advance, and was carried out at a time that took Beijing by surprise. Last but not least, the PKI exiles who stayed in China after G30S were mostly consumed with the political campaigns within the People's Republic during the Cultural Revolution, and thus unlikely to have joined the armed struggle of the remaining PKI members back in Indonesia. 